\title{
Geochemical Characterization and Saturation Index (Si) in the Montebello Lagunar System Liquidamber Lagoon, Chiapas Mexico
}

\author{
J. R. Reyes-Santiago, L. A. García-Villanueva†, G. Fernández-Villagómez and P. Guzmán-Guadarrama \\ Department of Sanitary and Environmental Engineering, Engineering School, National Autonomous \\ University of Mexico, Mexico \\ Corresponding author: L.A.García-Villanueva; lagvillanueva@ingenieria.unam.edu
}

Nat. Env. \& Poll. Tech. Website: www.neptjournal.com

Received: $20-06-2020$

Revised: $30-09-2020$

Accepted: 18-10-2020

Key Words:

Agricultural waste

Erosion risk

Loss of fertile soil

Water quality

\begin{abstract}
The "Lagunas de Montebello" National Park located in Chiapas, Mexico, is well known for its crystal blue water bodies, some of which, in 2003 , started to change color from crystalline to cloudy brown, and occasionally emit a foul smell, contains white-yellowish supernatant debris and dead fish. To determine the causes of the changes in the water characteristics of the "Liquidambar" lagoon of the Montebello lagoon system, a physicochemical characterization was carried out over the first six meters of the water column, together with geochemical speciation analysis and the saturation index calculation for different minerals. Water was classified as calcium-sulfated and the main mechanism that controlled its chemistry was rocks dissolution. Sulfide was found at all sampled depths in the range of 0.11 to 1.13 $\mathrm{mg} . \mathrm{L}^{-1}$. The concentration of sulfate in the water column ranged from 249.21 to $298.7 \mathrm{mg} . \mathrm{L}^{-1}$, carbonate ranged from 140.5 to $261.4 \mathrm{mg} . \mathrm{L}^{-1}$, calcium and magnesium ranged from 94.5 to $146.9 \mathrm{mg} . \mathrm{L}^{-1}$ and 34.2 to $38.3 \mathrm{mg} \cdot \mathrm{L}^{-1}$, respectively. Likewise, oxygen was also found to be oversaturated on the surface with a value of $9.32 \mathrm{mg} \cdot \mathrm{L}^{-1}$. The speciation results and SI indicated that the mineral phases calcite, aragonite, and dolomite were oversaturated, being greater on the surface. The results suggested the possibility that the turbidity, the coloration change, and the whitish supernatant were due to the precipitation of carbonate minerals, microbiologically influenced by the photosynthetic activity in the upper layer of the lagoon water.
\end{abstract}

\section{INTRODUCTION}

Geochemistry studies the redistribution of the elements and compounds through natural and anthropogenic environments, and in the case of water, it studies the processes that control its chemical composition. These processes are identified through the analysis of the water physicochemical parameters, which allows identifying characteristics acquired by its interaction with geological mediums such as quality, origin, the type of rocks through which it flows, its flow patterns, and even the residence time in the watershed and aquifers (Appelo \& Postma 2005, García et al. 2014, Nordstrom \& Campbell 2014)

The main processes that control water chemistry are atmospheric precipitation, dissolution of the crust minerals, and evaporation (Appelo \& Postma 2005, Marandi \& Shand 2018, Zhu \& Schwartz 2010).

Some other mechanisms that modify the water chemistry are processes that involve chemical reactions, such as silicates dissolution, which requires acid-base reactions, redox reactions, most of them biologically assisted, that exert a significant influence over some elements such as $\mathrm{O}, \mathrm{C}, \mathrm{S}$,
$\mathrm{N}$, and Fe. Ion exchange and absorption can also be mentioned as processes that influence water chemistry (Appelo \& Postma 2005, Singhal \& Gupta 2010, Stumm 2007, Zhu \& Schwartz 2010).

The dissolution and precipitation of minerals, as well as ion exchange, are rapid processes that are controlled by chemical equilibrium. On the contrary, redox transformations and silicates dissolution, are slow processes and controlled by kinetics. The majority of water solutes produced by the above-described processes are $\mathrm{Ca}^{2+}, \mathrm{Na}^{+}, \mathrm{Mg}^{2+}, \mathrm{K}^{+}, \mathrm{HCO}_{3}^{-}$, $\mathrm{Cl}^{-}, \mathrm{SO}_{4}{ }^{2-}$ and $\mathrm{H}_{4} \mathrm{SiO}_{4}$ and the source of these is described in Table 1 (Zhu \& Schwartz 2010).

Mineral saturation calculations using the saturation index (SI) can assist in predicting the existence of reactive minerals. This is defined as (Appelo \& Postma 2005):

$$
\mathrm{SI}=\log (\mathrm{AIP} / \mathrm{Ksp})
$$

Where IAP is the ion activity product, which is obtained from the water chemical analysis, and Ksp is the solubility product constant. When $\mathrm{SI}=0$, the balance between dissolved ions and a solid mineral has been reached, that is, saturation has been reached. On the other hand, SI $>0$ indicates over- 
Table 1: Origin of the main chemical water components.

\begin{tabular}{|ll|}
\hline Component & Source \\
\hline $\mathrm{Na}^{+}$ & Feldspar, rock salt, zeolite, atmosphere, cation exchange \\
$\mathrm{K}^{+}$ & Feldspar, mica \\
$\mathrm{Mg}^{2+}$ & Dolomite, serpentite, pyroxene, amphibole, olivine, mica \\
$\mathrm{Ca}^{2+}$ & Carbonate, gypsum, feldspar, pyroxene, amphibole \\
$\mathrm{Cl}^{-}$ & Rock salt, atmosphere \\
$\mathrm{HCO}_{3}^{-}$ & Carbonates, organic matter \\
$\mathrm{SO}_{4}{ }^{2-}$ & Atmosphere, gypsum, sulfides \\
$\mathrm{NO}_{3}^{-}$ & Atmosphere, organic matter \\
$\mathrm{Si}^{-}$ & Silicate \\
$\mathrm{Fe}^{2+}$ & Silicates, Siderite, Hydroxides, Sulfides \\
$\mathrm{PO}_{4}{ }^{3+}$ & Organic matter, phosphates \\
\hline
\end{tabular}

Source: Appelo \& Postma (2005)

saturation, so the mineral will tend to precipitate to achieve balance. When $\mathrm{SI}<0$, water is under saturated with respect to the mineral phase, so it will tend to dissolve until the balance is reached (Appelo \& Postma 2005).

Mineral precipitation occurs when the IAP that compose it, exceeds the Kps. For precipitation to occur, an oversaturation condition must exist. In natural water bodies, it has been observed that an SI $>1$ is required, i.e., the IAP is 10 times the value of Kps (Appelo \& Postma 2005, Dupraz et al. 2009, Homa \& Chapra 2011).

The minerals precipitation mediated by microorganisms can be classified according to their degree of intervention in the process. The secretion of one or more metabolic by-products that react with ions or chemicals in the environment, resulting in mineral particle deposition, is known as biologically induced precipitation. It is especially significant in anaerobic environments or oxic-anoxic interfaces because the source of electron acceptors are sulfates and/or various metals including iron and manganese. On the other hand, biologically controlled precipitation is that in which biological activity controls nucleation, growth, morphology, and the final location of minerals; some examples of it are the formation of shells and exoskeletons. Finally, biologically influenced precipitation is that in which environmental parameters, rather than microbial activity, are responsible for precipitation. In this case, microorganisms exercise some influence over the environment, leading to precipitation, for example, the carbon minerals precipitation derived from the increase of $\mathrm{pH}$ generated by photosynthesis (Dupraz et al. 2009, Homa \& Chapra 2011).

Photosynthesis is one of the most effective biological processes in biologically influenced precipitation in aquatic environments with hard water. Photosynthetic carbon fixation removes $\mathrm{CO}_{2}$ from the environment, sometimes at a faster rate than the diffusion replacement to the higher activity layer, resulting in $\mathrm{HCO}_{3}{ }^{-}$dissociating to $\mathrm{CO}_{2}$ and $\mathrm{OH}^{\prime}$ raising the $\mathrm{pH}$ and favoring the precipitation of $\mathrm{CaCO}_{3}$. At the same time, $\mathrm{CO}_{2}$ removal displaces the balance towards calcium carbonate formation. The net reaction of $\mathrm{CaCO}_{3}$ photosynthesis and precipitation process is (Dupraz et al. 2009, Homa \& Chapra 2011, Karami et al. 2019).

$$
2 \mathrm{HCO}_{3}{ }^{-}+\mathrm{Ca}^{2+}=\mathrm{CaCO}_{3}+\mathrm{CH}_{2} \mathrm{O}+\mathrm{O}_{2}
$$

The $\mathrm{CaCO}_{3}$ formation has more than one environmental impact, since calcite precipitation, when oversaturated, causes reduction of water clarity (Karami et al. 2019, Walsh et al. 2019)

Abiotically, the physicochemical processes that lead to precipitation are: water evaporation (which concentrates the ions until reaching saturation), and degassing (which modifies the carbonates balance favoring precipitation) (Dupraz et al. 2009).

The "Lagunas de Montebello" National Park, located in the state of Chiapas, Mexico, is a protected natural area that houses a karstic origin lagoon system formed by approximately sixty lagoons that vary in size and shape. The park houses some of the most beautiful scenery in the Mexican territory, largely for the water color and clarity of its lagoons (Durán et al. 2014, IMPLAN Comitán 2015).

For decades, the region's socio-economic pressure to land-use change, deforestation, the increase in agricultural and livestock activities, as well as the increase of population, have altered water quality in the basin (IMPLAN Comitán 2015, Mora et al. 2017). 
In 2003, residents of the Liquidambar Lagoon area began to report water changes in the coloration and transparency of the water, as well as whitish-yellow supernatant debris, bubbling, foul odor, and fish death. This phenomenon, with the passage of time, has been identified in other lagoons too, and it commonly occurs between December to February (Alcocer et al. 2016, 2018, García et al. 2014, IMPLAN Comitán 2015, Mora et al. 2017, Oseguera \& Alcocer 2016).

Studies have been carried out for the physical, chemical, biological and toxicological characterization of the Lagunar System of Montebello, Chiapas. However, the causes of spatial and temporal change in the water quality of the lagoons have not been identified (CONAGUA - CONACYT 2013).

\section{STUDY AREA}

The Lagunas de Montebello National Park is in the state of Chiapas in Mexico and borders Guatemala. It is delimited by the coordinates $16^{\circ} 5^{\prime}$ and $16^{\circ} 10^{\prime}$ latitude and $91^{\circ} 38^{\prime}$ and $91^{\circ} 97^{\prime}$ longitude (Fig. 1). It covers an area of approximately $61 \mathrm{~km}^{2}$, and it is located at the southeastern end of the Río Grande basin in Comitán ( CONAGUA - CONACYT 2013, Durán et al. 2014, Mora et al. 2017).

This region's climate is semi-humid temperate with rainfall all year long, the total average precipitation is $1800 \mathrm{~mm}$, and the annual average temperature is $17^{\circ} \mathrm{C}$. The Montebello Lagunar System is composed of about sixty lagoons, some of which are superficially connected. However, the waters that feed the system are mainly underground and are part of the
Rio Grande basin in Comitán (Durán et al. 2014, IMPLAN Comitán 2015, Mora et al. 2017).

The soil of the system is predominantly composed of sedimentary cretaceous rocks, chemically limestone, and dolomites. At greater depth, paleocene turbidite can be found. Finally, there are Eocene and Miocene units composed of continental clastic deposits (Durán et al. 2014, Mora et al. 2016).

The Lagunar system of Montebello Park is composed of 50-60 water bodies. Some of the main bodies are Balamtetik, Liquidambar, San Lorenzo, Yalmuz, Bosque Azul, Monte Bello, Cinco Lagos, Pojoj, Tziscao, and Dos Lagunas, which stand out for their size, morphology, and economic importance, as well as for being subjects of study (Alcocer et al. 2016, Mora et al. 2017).

According to their water chemistry, the lagoons can be classified into two large groups: lagoons with carbonate calcium water and lagoons with sulfate calcium water. The lagoons in the first group receive the discharge from the Rio Grande, and have been classified as eutrophic, and mesotrophic (Durán et al. 2014, Mora et al. 2017, Vera et al. 2015).

\section{MATERIALS AND METHODS}

\section{Sampling}

The sampling was performed in the Liquidambar Lagoon in July of 2018. The change of color was observed for the

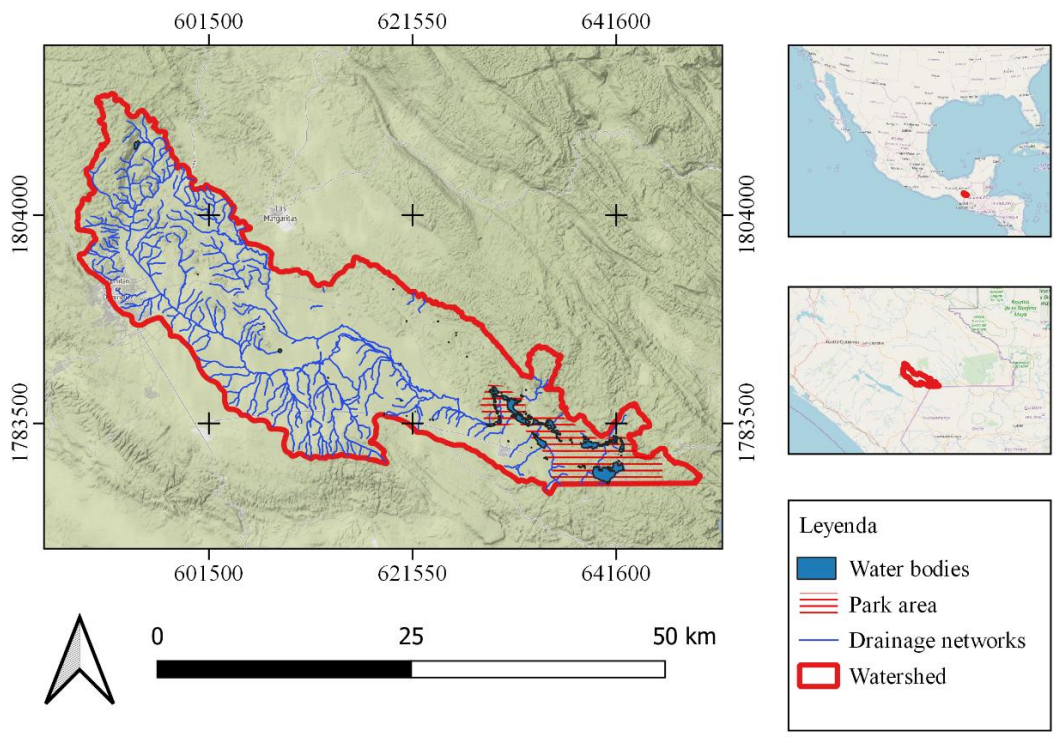

Fig. 1: Geographical location of the Lagunas de Montebello National Park Source: Modified from SIATL-INEGI 
first time in this lagoon (Vera et al. 2015). The sampling point coordinates are latitude 1786736, length 629915, UTM projection; Datum WGS 84 (Fig. 2), with an elevation of 1457 masl.

The samples were taken with a Van Dorn bottle, at 7 different depths, the first at $0.5 \mathrm{~m}$ under the water mirror and later at 1, 2, 3, 4, 5, and $6 \mathrm{~m}$. They were filtered through a 0.45 -micron nitrocellulose membrane of $25 \mathrm{~mm}$ diameter. To provide pressure, swinnex filter holders and a $5 \mathrm{~mL}$ syringe were used. Samples taken for ion analysis were stored in 50 $\mathrm{mL}$ corning polypropylene centrifuge tubes.

For the sulfide samples, 8 drops of $2 \mathrm{~N}$ zinc acetate were added as a preservative and 4 drops of $\mathrm{NaOH} 6 \mathrm{~N}$ to bring the sample to a $\mathrm{pH}$ above 8 , and ensure that the sulfides remain dissolved when the zinc sulfide precipitate is formed.

For the biochemical oxygen demand $\left(\mathrm{BOD}_{5}\right)$, chemical oxygen demand (COD), and alkalinity tests, one-liter polypropylene bottles were filled completely, without leaving air space. The samples were kept on ice until analysis.

\section{Sample Characterization.}

For the field parameters (temperature, $\mathrm{pH}$, dissolved oxygen (DO), redox potential (EH)) a multiparametric Hanna Instruments model HI 9829 probe was used.

Alkalinity was determined by volumetric titration using $\mathrm{HCl} 0.02 \mathrm{~N}$ to the turn of bromocresol green; the determina- tion was made within $7 \mathrm{~h}$ after the first sampling.

The dissolved anions and cations, except for sulfide, were analyzed using the chromatography technique of ions with conductometric detection.

The ion sulfide concentration determination was done by reverse titration. An excess iodine solution of $0.0025 \mathrm{~N}$ was added to the sample to react with the sulfide, then the remaining iodine was titrated with sodium thiosulphate $0.0025 \mathrm{~N}\left(\mathrm{Na}_{2} \mathrm{~S}_{2} \mathrm{O}_{3}\right)$ using starch as an indicator, method 4500-S2- F (Clescerl et al. 1999). The COD was analyzed using the Hach reagent kit "COD ultra-low range" which has a measurement range of 1 to $40 \mathrm{mg} . \mathrm{L}^{-1}$ and consists of a closed reflux test.

The ultimate carbonaceous biochemical oxygen demand (U-CBOD) was performed using Winkler bottles following the technique for BOD5 (5210 B) using 2-chloro-6-(trichloromethyl) pyridine (TCMP 2-Chloro-6-(trichloromethyl) pyridine) as nitrification inhibitor, and resaturating oxygen when it reached $2 \mathrm{mg} . \mathrm{L}^{-1}$ values, (Clescerl et al. 1999). The values were taken for 60 days until there was no more oxygen consumption. An equipment YSI model 58 YSI was used for measuring DO.

\section{Modeling Focus}

Before starting the analysis and interpretation of the data, the review of the chemical data quality collected during

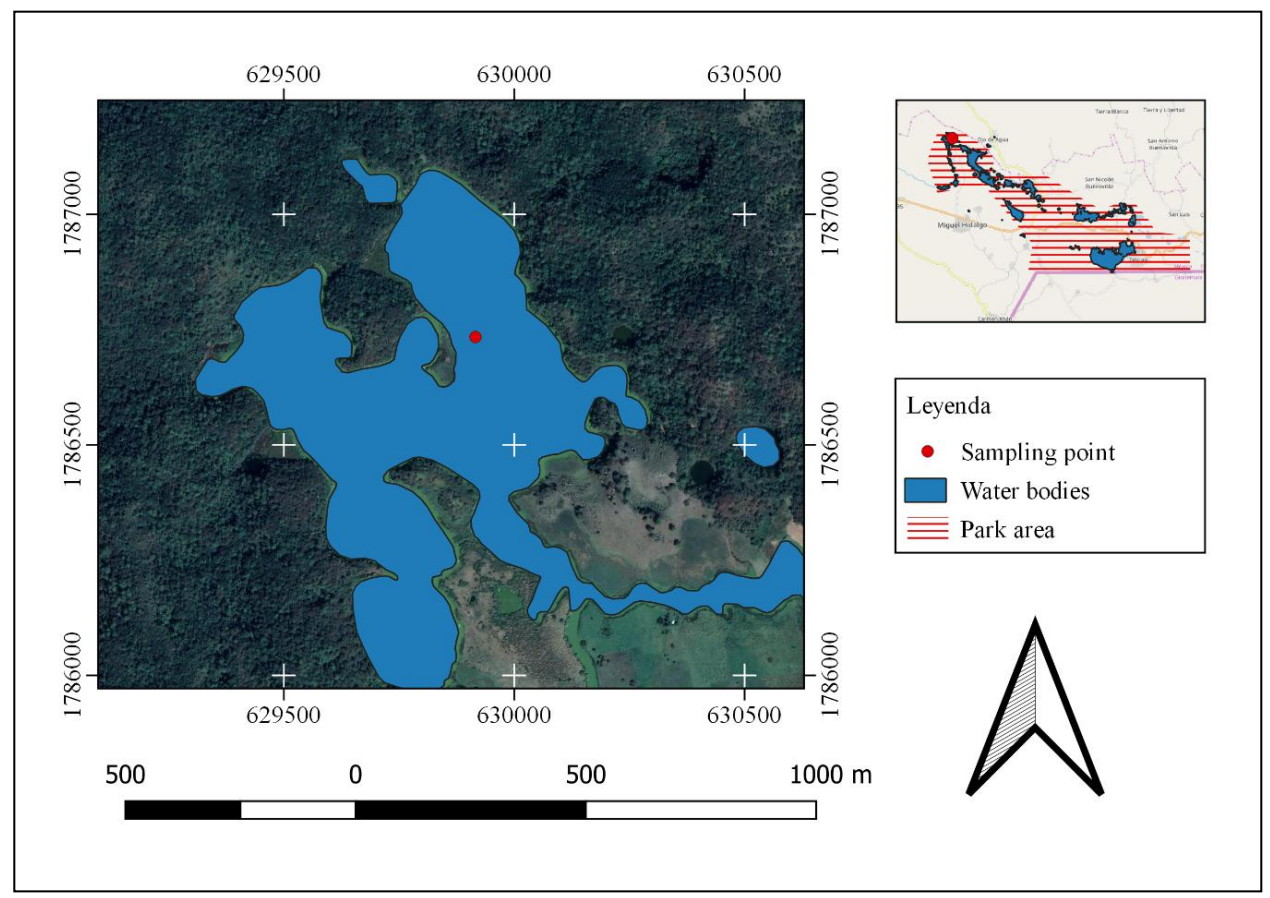

Fig. 2: Sample site. 
sampling and samples characterization is necessary. The ionic balance of the collected samples had an error of less than 5\% in all cases (Zhu \& Anderson 2010). To identify the family to which water belongs, and the geochemical processes that control the water chemistry in the Liquidambar lagoon, chemical data was used to generate diagrams of Piper, Gibbs, and Stiff.

To determine whether the minerals in the water precipitate, dissolve, or are in balance, a geochemical speciation analysis was performed, and saturation rates of minerals of interest and those that might be present were obtained, using the numerical model PHREEQC version 3.0 and the minteqv4 database (Parkhurst \& Appelo 2013).

\section{RESULTS AND DISCUSSION}

\section{Physicochemical Characterization of Water}

Table 2 shows the Liquidambar lagoon water physico-chemical characteristics sampled in July 2018. The lagoon was found stratified with clinogram profiles for temperature, $\mathrm{pH}, \mathrm{EH}, \mathrm{DO}, \mathrm{Cl}-, \mathrm{Na}^{+}$, and $\mathrm{K}^{+}$. The properties that showed ortho profiles were TDS, EC, U-CBOD, COD, alkalinity, $\mathrm{S}^{2-}, \mathrm{HCO}_{3}^{-}, \mathrm{SO}_{4}{ }^{2-}, \mathrm{Ca}^{2+}$ and $\mathrm{Mg}^{2+}$.

The clines, or change areas, were observed at different depths, being able to categorize the properties in two groups according to the observed profile, from 2 to $5 \mathrm{~m}$, for temperature, $\mathrm{pH}$, alkalinity, TDS, EC, and $\mathrm{EH}$, and from 4 to $5 \mathrm{~m}$, for $\mathrm{Cl}^{-}, \mathrm{Mg}^{2+}, \mathrm{Ca}^{2+}, \mathrm{HCO}_{3}{ }^{-}, \mathrm{Na}^{+}, \mathrm{SO}_{4}{ }^{2-}$ and $\mathrm{K}^{+}$.

The concentration variations between the surface and the $6 \mathrm{~m}$ were $120.9 \mathrm{mg} . \mathrm{L}^{-1}$ for bicarbonates, $52.4 \mathrm{mg} . \mathrm{L}^{-1}$ for calcium, $49 \mathrm{mg} . \mathrm{L}^{-1}$ for sulfates, $4.06 \mathrm{mg} . \mathrm{L}^{-1}$ for magnesium, $-2.86 \mathrm{mg} . \mathrm{L}^{-1}$ for sodium, $-0.28 \mathrm{mg} . \mathrm{L}^{-1}$ for potassium, and at last, -0 . mg. $\mathrm{L}^{-1}$ for chlorides and 1.01 for S(II-).

The $\mathrm{NO}_{3}{ }^{-}, \mathrm{NO}_{2}{ }^{-}, \mathrm{PO}_{4}{ }^{3-}, \mathrm{Br}^{-}, \mathrm{F}^{-}$concentrations were found below the technique detection limit and could not be determined. The $\mathrm{NH}_{4}^{+}$could be found at 5 and 6-m depth with values of 2.05 and $2.25 \mathrm{mg} . \mathrm{L}^{-1}$ respectively- at the upper points the concentration was below the detection limit.

For physicochemical properties, these variations were -1.06 for $\mathrm{pH},-3.3^{\circ} \mathrm{C}$ for temperature, $222.8 \mathrm{mg} . \mathrm{L}^{-1}$ for TDS, $86 \mathrm{mg} . \mathrm{L}^{-1}$ for alkalinity, and -406 for $\mathrm{EH}$. The variation reported by DO was $6.01 \mathrm{mg} . \mathrm{L}^{-1}$, while for dissolved U-CBOD it was $7.5 \mathrm{mg} \cdot \mathrm{L}^{-1}$.

The different profiles developed from the variables of the Laguna Liquidambar water are shown in Fig. 3.

\section{Hydrogeochemical Classification}

The Piper graph (Fig. 4) shows that water from the Liquidambar Lagoon can be classified as sulfated calcium-type

Table 2: Summary of the main physiochemical characteristics of the water in Laguna Liquidambar.

\begin{tabular}{|c|c|c|c|c|c|c|c|c|c|}
\hline Sample & $\begin{array}{l}\text { Depth } \\
{[\mathrm{m}]}\end{array}$ & $\begin{array}{l}\mathrm{T} \\
{\left[{ }^{\circ} \mathrm{C}\right]}\end{array}$ & $\mathrm{pH}$ & $\begin{array}{l}\text { TDS } \\
{[\mathrm{ppm}]}\end{array}$ & $\begin{array}{l}\mathrm{EC} \\
{\left[\mu \mathrm{S} . \mathrm{cm}^{-1}\right]}\end{array}$ & $\begin{array}{l}\mathrm{EH} \\
{[\mathrm{mV}[}\end{array}$ & $\begin{array}{l}\text { U-CBOD } \\
{\left[\mathrm{mg} \cdot \mathrm{L}^{-1}\right]}\end{array}$ & $\begin{array}{l}\text { Alkalinity } \\
{\left[\mathrm{mg} \cdot \mathrm{L}^{-1}\right]}\end{array}$ & $\begin{array}{l}\text { DO } \\
{\left[\mathrm{mg} \cdot \mathrm{L}^{-1}\right]}\end{array}$ \\
\hline L0 & 0.5 & 25.5 & 8.3 & 543.7 & 414.0 & 400.9 & 305.5 & 90.0 & 9.3 \\
\hline L1 & 1.0 & 25.3 & 8.2 & 541.8 & 408.0 & 394.6 & 260.7 & 92.0 & 6.9 \\
\hline L2 & 2.0 & 25.4 & 8.2 & 538.9 & 409.0 & 406.7 & 239.4 & 92.0 & 6.0 \\
\hline L3 & 3.0 & 24.3 & 7.7 & 579.9 & 429.0 & 76.5 & 249.2 & 118.0 & 5.5 \\
\hline L4 & 4.0 & 23.6 & 7.7 & 614.9 & 448.0 & 33.7 & 198.5 & 124.0 & 5.0 \\
\hline L5 & 5.0 & 22.9 & 7.2 & 734.8 & 506.0 & -4.2 & 351.6 & 168.0 & 3.8 \\
\hline L6 & 6.0 & 22.2 & 7.3 & 766.5 & 526.0 & -5.1 & 508.2 & 176.0 & 3.3 \\
\hline
\end{tabular}

Table 2 Cont...

\begin{tabular}{|c|c|c|c|c|c|c|c|c|c|}
\hline Sample & $\begin{array}{l}\text { Depth } \\
{[\mathrm{m}]}\end{array}$ & $\begin{array}{l}\mathrm{S}^{2-} \\
{\left[\mathrm{mg} . \mathrm{L}^{-1}\right]}\end{array}$ & $\begin{array}{l}\mathrm{HCO}_{3}^{-} \\
{\left[\mathrm{mg} . \mathrm{L}^{-1}\right]}\end{array}$ & $\begin{array}{l}\mathrm{Cl}^{-} \\
{\left[\mathrm{mg} \cdot \mathrm{L}^{-1}\right]}\end{array}$ & $\begin{array}{l}\mathrm{SO}_{4}{ }^{2-} \\
{\left[\mathrm{mg} \cdot \mathrm{L}^{-1}\right]}\end{array}$ & $\begin{array}{l}\mathrm{Na}^{+} \\
{\left[\mathrm{mg} \cdot \mathrm{L}^{-1}\right]}\end{array}$ & $\begin{array}{l}\mathrm{K}^{+} \\
{\left[\mathrm{mg} . \mathrm{L}^{-1}\right]}\end{array}$ & $\begin{array}{l}\mathrm{Ca}^{2+} \\
{\left[\mathrm{mg} \cdot \mathrm{L}^{-1}\right]}\end{array}$ & $\begin{array}{l}\mathrm{Mg}^{2+} \\
{\left[\mathrm{mg} \cdot \mathrm{L}^{-1}\right]}\end{array}$ \\
\hline L0 & 0.5 & 0.11 & 140.5 & 9.9 & 249.6 & 11.9 & 3.1 & 94.5 & 34.2 \\
\hline L1 & 1.0 & 0.11 & 136.3 & 10.2 & 251.8 & 11.4 & 3.1 & 94.6 & 34.3 \\
\hline L2 & 2.0 & 0.15 & 132.7 & 11.1 & 249.2 & 11.8 & 4.3 & 95.3 & 34.4 \\
\hline L3 & 3.0 & 0.16 & 160.3 & 12.2 & 252.6 & 11.5 & 3.5 & 105.5 & 34.4 \\
\hline L4 & 4.0 & 0.18 & 181.4 & 10.6 & 260.5 & 11.7 & 3.0 & 112.2 & 35.5 \\
\hline L5 & 5.0 & 0.84 & 229.2 & 9.2 & 302.1 & 8.7 & 3.0 & 144.4 & 38.2 \\
\hline L6 & 6.0 & 1.13 & 261.4 & 9.3 & 298.7 & 9.0 & 2.8 & 146.9 & 38.3 \\
\hline
\end{tabular}


water (Singhal \& Gupta 2010). Likewise, it is observed that all samples are located in areas 1, 4, and 6 of the diagram, so it can be noticed that the alkaline earth elements exceed the alkaline, the strong acids exceed the weak acids, and the carbonated hardness exceeds $50 \%$.

The Liquidambar Lagoon water is located in the "Rock Dominance" area, according to the Gibbs graph (Fig. 5), as the process that controls the water chemistry is the dissolution of the medium, which indicates that the water in the lagoon is partially in equilibrium with the basin material (Appelo \& Postma 2005, Marandi \& Shand 2018).

In the Stiff graph (Fig. 6) it can be observed that at greater depth the calcium, magnesium, bicarbonate, and sulfate ions have a higher concentration. For sodium, potassium, and chlorides there is a slight decrease as depth increases.

Similarly, the graphs for Piper, Stiff (Fig. 5 and Fig. 6) show that surface water, compared to bottom water, has a lower concentration of total dissolved solids. This variation can be attributed to rainwater since, in the Gibbs graph (Fig. 4). Surface samples move away to the area where the main mechanism controlling the water chemistry is atmospheric precipitation. The Stiff graph also shows that sodium and chlorides increase their concentration as they approach the surface, indicating atmospheric input (Appelo \& Postma 2005, Singhal \& Gupta 2010).

\section{Saturation State}

The results show that all the depths studied are oversaturated with respect to the calcite mineral phase, having on the surface the maximum value, which is 0.86 . On the other hand, the samples showed oversaturation with respect to the mineral phase's aragonite and dolomite (ordered and disorderly) in the first $4 \mathrm{~m}$ of the water column, having a maximum of 0.68 for aragonite and 1.66 for ordered dolomite. The SI of the three calcium minerals decreases with respect to depth.

On the other hand, the SI for gypsum is between -1.19 and -0.98 , indicating that the gypsum dissolution process can continue (Appelo \& Postma 2005).

The saturation index calculation results suggest that a carbonate precipitation bleaching event may happen (whiting event), which is a phenomenon that occurs in the water column of hard water lakes during the productive warm pe-
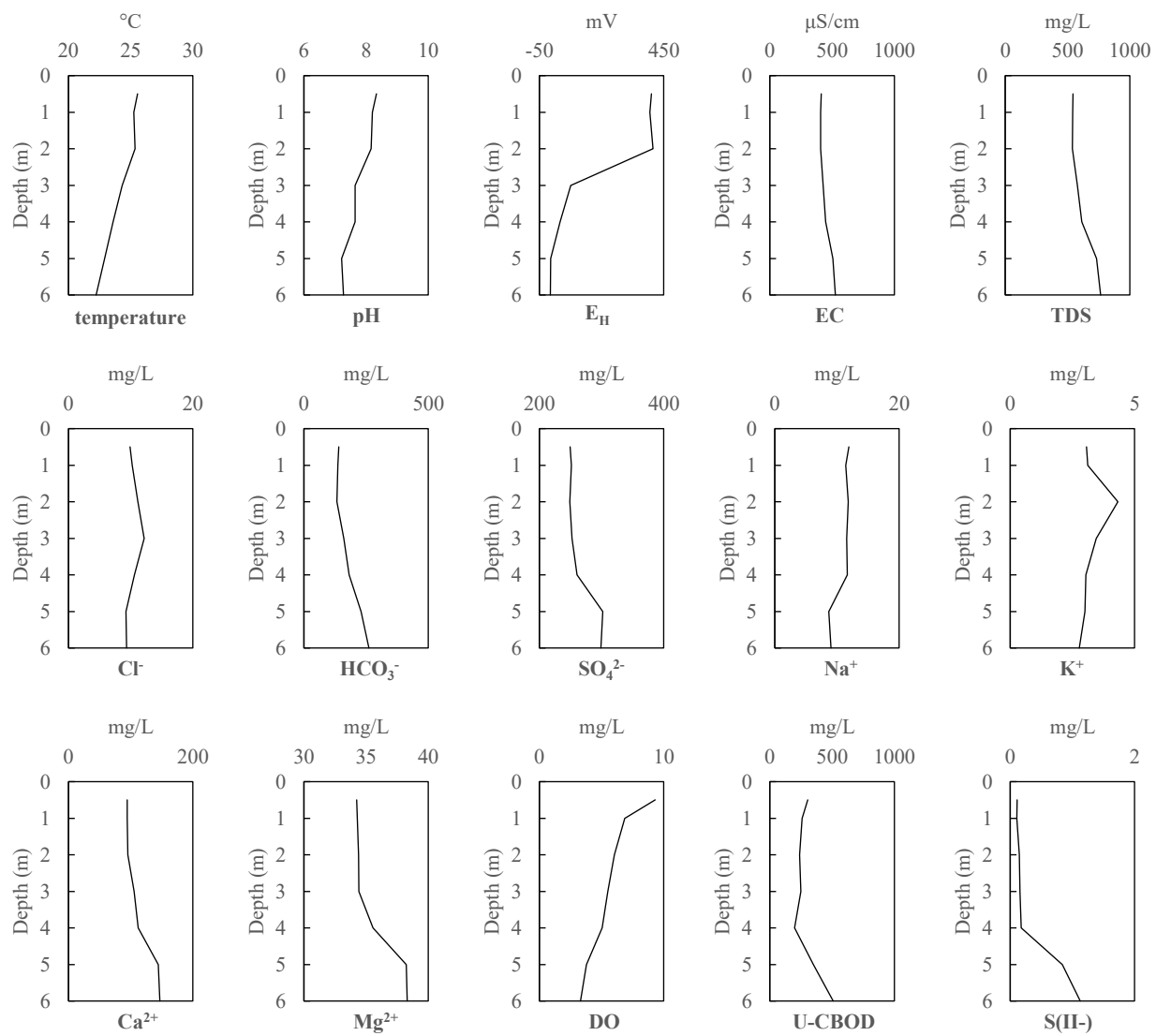

Fig. 3: Physiochemical properties profiles for water in the Liquidambar Lagoon. 


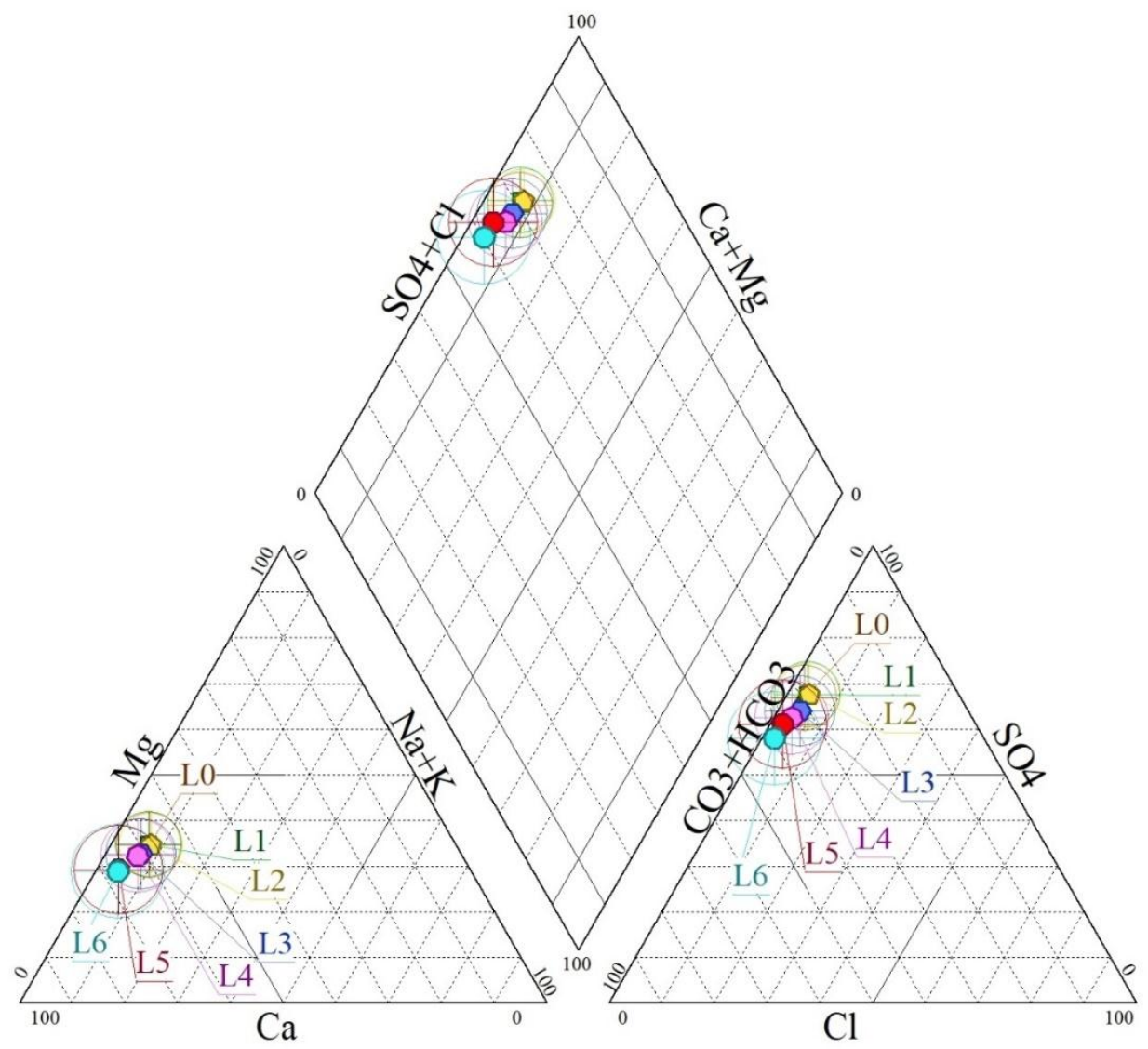

Fig. 4: Piper diagram of the water in Liquidambar Lagoon.

riod. This is one of the forms of internal inorganic particles production that provides turbidity and is a light attenuation component (Dupraz et al. 2009, Karami et al. 2019, Walsh et al. 2019).

Some studies indicate that carbonate precipitation occurs both biotically and abiotically induced, being photosynthesis, the process that most influences carbonate mineral precipitation, by increasing $\mathrm{pH}$ dissociating bicarbonate $\left(\mathrm{HCO}_{3}{ }^{-}\right)$into carbon dioxide $\left(\mathrm{CO}_{2}\right)$ and hydroxide ions $\left(\mathrm{OH}^{-}\right)$, which in turn reduces the solubility of carbonate minerals. Likewise, degassing $\mathrm{CO}_{2}$ is another process that impacts the solubility of carbonates by altering the equilibrium of the dissolution reaction of $\mathrm{CaCO}_{3}$ (Dupraz et al. 2009).

As shown in Table 2, the $\mathrm{pH}$ is higher on the surface and descends with depth, which explains a higher SI of carbonate minerals on the surface (Appelo \& Postma 2005). Likewise, the oxygen oversaturation on the surface with a value of 9.32 mg. $L^{-1}$ (Table 2) suggests photosynthetic activity, so this could be the cause of the increase in $\mathrm{pH}$. Finally, speciation results show that the concentration of $\mathrm{CO}_{2}$ in lagoon water exceeds saturation. According to Henry's law, the partial atmospheric $\mathrm{CO}_{2}$ pressure that would correspond to the $\mathrm{CO}_{2}$ concentration of water is $6.02 \times 10^{-4} \mathrm{~atm}$, considering the partial atmospheric $\mathrm{CO}_{2}$ pressure of $4.08 \times 10-4 \mathrm{~atm}$. This suggests that the degassing process is occurring, which would be an additional factor contributing to the increase in SI on the surface (Dupraz et al. 2009, Karami et al. 2019, Stumm 2007).

A graphical comparison of the SI profiles in the water column (Table 3, Fig. 7) shows the effect of depth on the SI of the main mineral phases in the water of the Liquidambar lagoon.

\section{Redox Conditions (State)}

According to the results, the $\mathrm{EH}$ in the water column is in the reduction range for $\mathrm{O}_{2}, \mathrm{Mn}^{4+}, \mathrm{Fe}^{2+}$ and $\mathrm{NO}_{3}^{-}$, as well as organic matter oxidation and in $\mathrm{S}^{2-}$. Two changes can be observed in the $\mathrm{EH}$ profile trend corresponding to the $\mathrm{Fe}^{3+} / \mathrm{Fe}^{2+}$ and $\mathrm{NO}_{3}{ }^{-} / \mathrm{NH}_{4}{ }^{+}$, transformations, which occur in the $100 \mathrm{mVy}$ and $400 \mathrm{mV}$ areas (Fig. 8) (Appelo \& Postma 2005, Stumm 2007). 


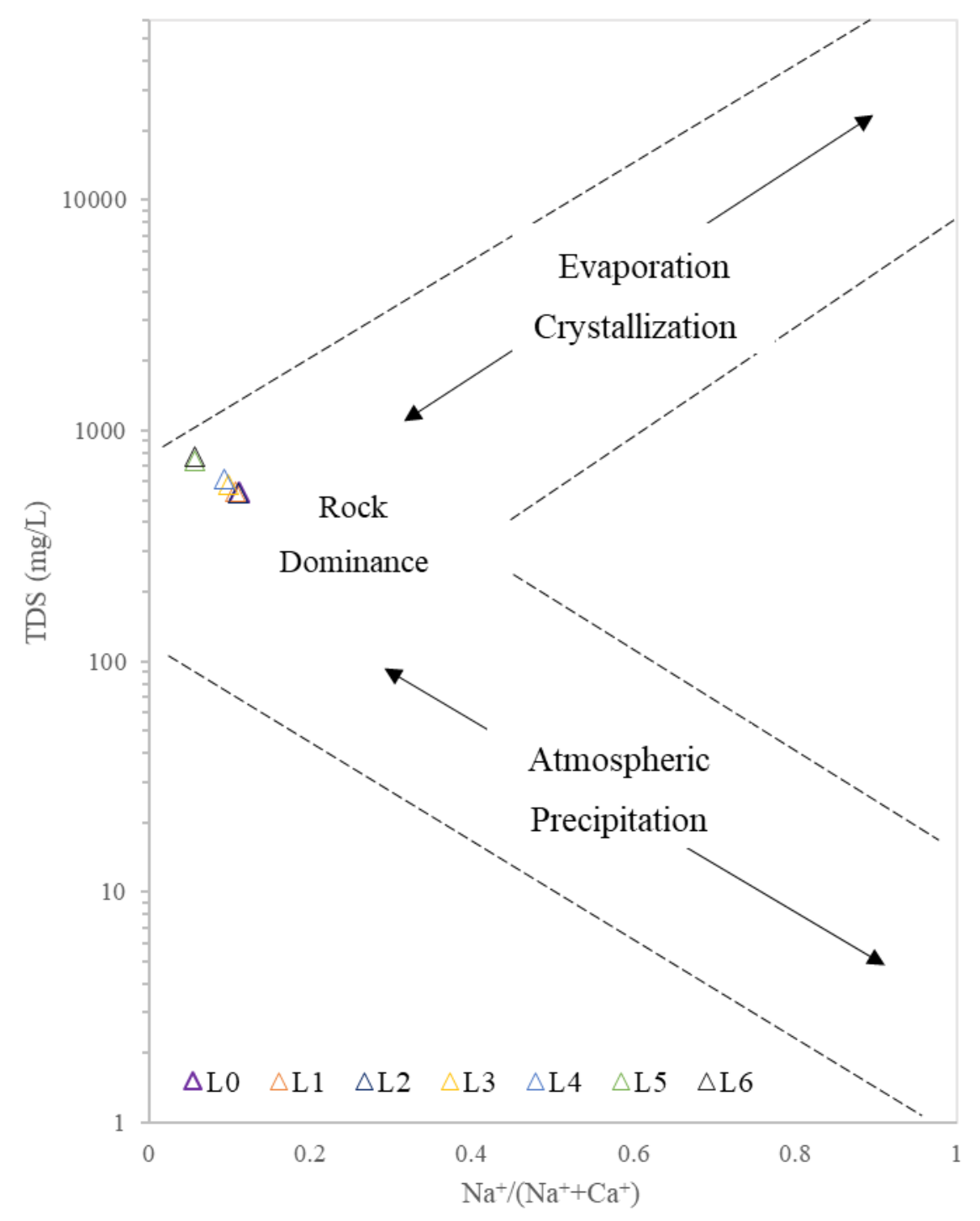

Fig. 5: Gibbs' diagram of water in the Liquidambar Lagoon.

Furthermore, $\mathrm{S}^{2-}$ was also observed in all the depths sampled, in coexistence with $\mathrm{O}_{2}$, so the suboxic zone was not defined (Murray et al. 1989). ([O $\left.\left.\mathrm{O}_{2}\right]<3 \mu \mathrm{M} ;\left[\mathrm{S}^{2-}\right]<0.2 \mu \mathrm{M}\right)$. Minimal concentrations were found at $103 \mu \mathrm{M}$ for $\mathrm{O}_{2}$ and $3.5 \mu \mathrm{M}$ for $\mathrm{S}^{2-}$. Due to the presence of oxygen, it is unlikely that the sulfate reduction reaction is occurring at the sampled depth, on the contrary, the coexistence of these turns out to be uncommon due to the oxygen presence, $\mathrm{S}^{2-}$ is rapidly oxidized (Hargrave et al. 2008). This coexistence occurs in oxy-anoxic transition zones mainly in sediments though, it has been observed also in the water column. Sulfide is rarely observed within anoxic environments (Findlay et al. 2014, Knossow et al. 2015), so it can be assumed that $S^{2-}$ is the result of diffusion transport or a recent mixing event in the water column.

Carbonaceous dissolved oxygen demand was found to be almost constant up to $4 \mathrm{~m}$ deep, where it increased substantially, possibly due to oxygen depletion. 


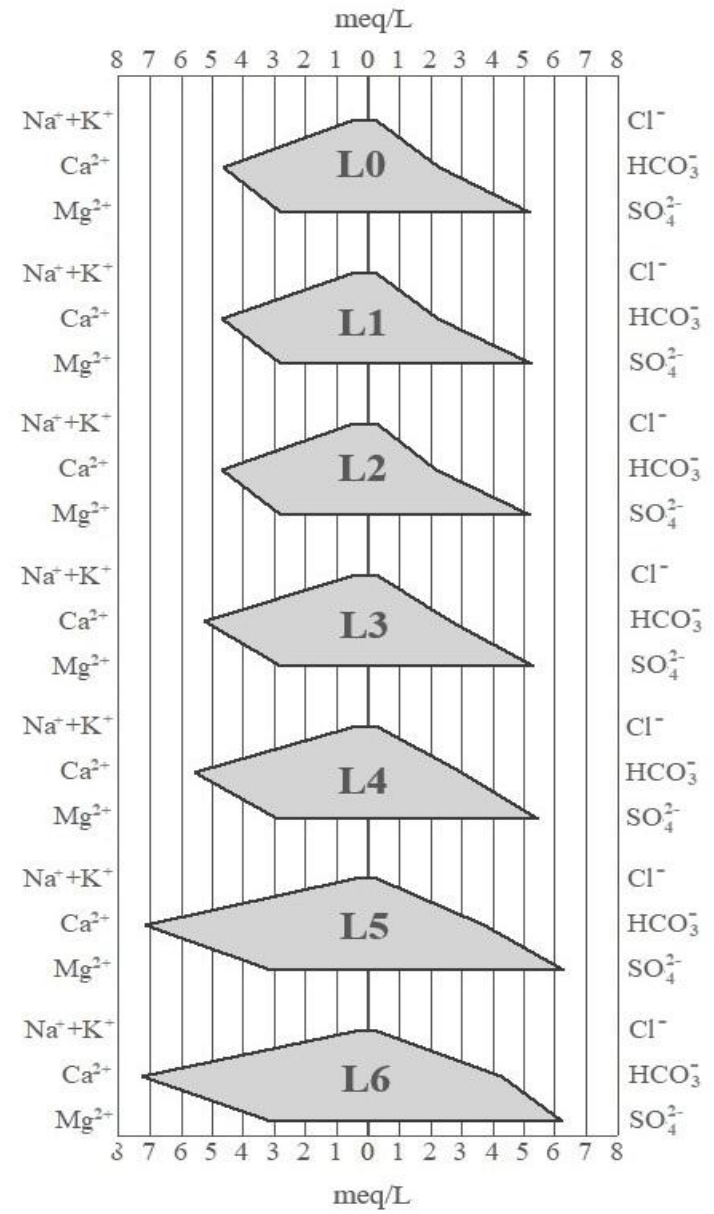

Fig. 6: Stiff diagram of the water in the Liquidambar lagoon

Table 3: SI of the main mineral phases in the water at the Liquidambar lagoon

\begin{tabular}{|c|c|c|c|c|c|c|c|c|c|}
\hline Sample & $\begin{array}{l}\text { Depth } \\
{[\mathrm{m}]}\end{array}$ & Anhydrite & Aragonite & Calcite & $\begin{array}{l}\text { Dolomite } \\
\text { [disordered] }\end{array}$ & $\begin{array}{l}\text { Dolomite } \\
\text { [ordered] }\end{array}$ & Gypsum & Huntite & Magnesite \\
\hline L0 & 0.5 & -1.44 & 0.68 & 0.86 & 1.11 & 1.66 & -1.19 & -1.08 & -0.37 \\
\hline L1 & 1 & -1.43 & 0.54 & 0.72 & 0.83 & 1.38 & -1.18 & -1.66 & -0.5 \\
\hline L2 & 2 & -1.43 & 0.5 & 0.68 & 0.74 & 1.29 & -1.18 & -1.84 & -0.55 \\
\hline L3 & 3 & -1.39 & 0.09 & 0.27 & -0.14 & 0.41 & -1.14 & -3.65 & -0.99 \\
\hline L4 & 4 & -1.37 & 0.15 & 0.34 & -0.04 & 0.52 & -1.11 & -3.46 & -0.92 \\
\hline L5 & 5 & -1.24 & -0.14 & 0.05 & -0.7 & -0.15 & -0.98 & -4.88 & -1.28 \\
\hline L6 & 6 & -1.24 & -0.02 & 0.17 & -0.49 & 0.08 & -0.98 & -4.45 & -1.15 \\
\hline
\end{tabular}

\section{CONCLUSION}

Based on the results it is concluded that the mineral phases of aragonite, calcite and dolomite are oversaturated so turbidity, color change, and whitish supernatant could be due to the precipitation of carbonate minerals, microbiologically influenced by photosynthesis activity in the upper layer of lagoon water.

Likewise, foul odor and death of fishes may happen due to the presence of sulfides in the surface layer of the lagoon, as well as their release during the mixing periods in the win- 


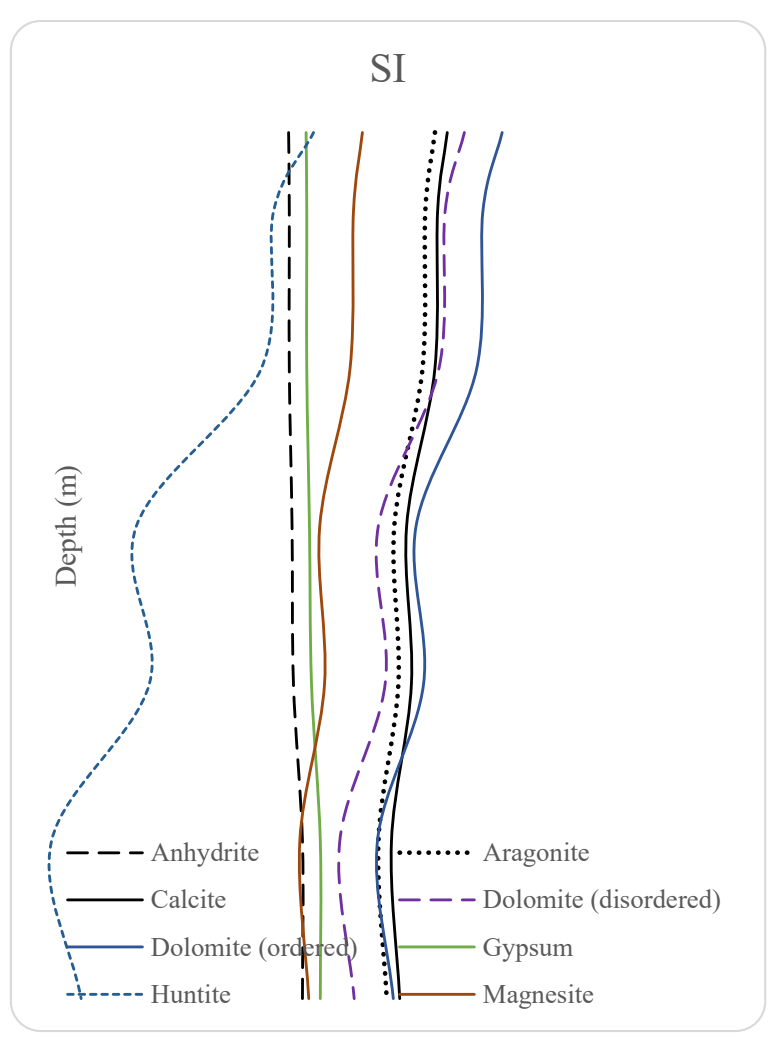

Fig. 7: The SI profiles of the main mineral phases in the Liquidambar lagoon water

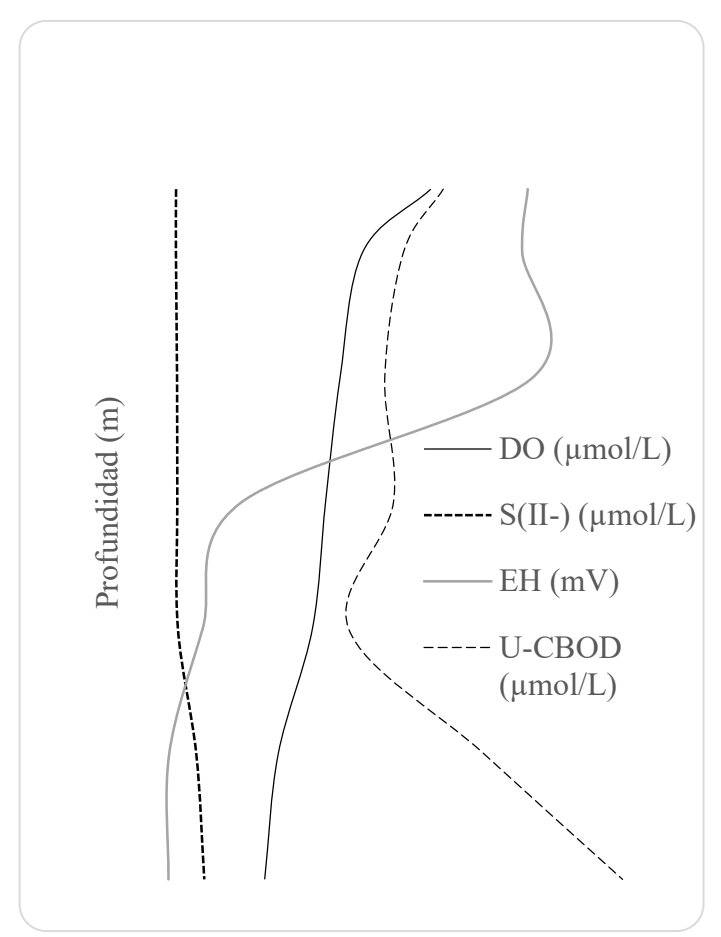

Fig. 8: Profiles of main redox species in the water of the Liquidambar lagoon 
ter season, combined with low oxygen concentrations and concentrations of organic matter measured as BOD.

\section{ACKNOWLEDGEMENT}

To the General Directorate of Academic Personnel Affairs (DGAPA), through the Program of Support for Research Projects and Technological Innovation (PAPIIT), for financial support to the project with code IA108117.

\section{REFERENCES}

Alcocer, J., Merino-Ibarra, M., Oseguera, L.A. and Escolero, O. 2018. Anthropogenic impacts on tropical karst lakes: "Lagunas de Montebello," Chiapas. Ecohydrology, 11(8), e2029.

Alcocer, J., Oseguera, L.A., Sánchez, G., González, C., Martínez, J. and González, R. 2016. Bathymetric and morphometric surveys of the Montebello Lakes, Chiapas. J. Limnol., 75: 11-19

Appelo, C.A.J. and Postma, D. 2005. Geochemistry, Groundwater, and Pollution. 2nd edition. CRC Press, Taylor \& Francis Group, London, UK.

Clescerl, L.S., Greenberg, A.E. and Eaton, A.D. (Eds.). 1999. Standard Methods for the Examination of Water and Wastewater: User Guide. 20th edition. The American Public Health Association, Washington DC, USA.

Comisión Nacional del Agua y Concejo Nacional de Ciencia y Tecnología (CONAGUA - CONACYT). 2013. Hydrological and Water Quality Study Of The Montebello Lagoon System, Chis. (No. 1). Mexico

Dupraz, C., Reid, R.P., Braissant, O., Decho, A.W., Norman, R.S. and Visscher, P.T. 2009. Processes of carbonate precipitation in modern microbial mats. Earth-Sci. Rev., 96(3): 141-162.

Durán, I., Escolero, O., Muñoz-Salinas, E., Rodríguez, M. and Silva-Romo, G. 2014. Geomorphological mapping at 1: 50000 scale of Lagunas de Montebello National Park, Chiapas (Mexico). Bullet. Mexican Geol. Soc., 66: 263-277.

Findlay, A. J., Gartman, A., MacDonald, D. J., Hanson, T. E., Shaw, T. J. and Luther, G. W. 2014. Distribution and size fractionation of elemental sulfur in aqueous environments: The Chesapeake Bay and the Mid-Atlantic Ridge. Geochim. Cosmochim. Acta, 142: 334-348.

García, L.A., Escolero, O. and Fernández, G. 2014. Hydrogeochemistry Lake San Lorenzo in Montebello, Chiapas (Mexico). Colombian Association of Sanitary and Environmental Engineering, Bogota, Columbia.

Hargrave, B.T., Holmer, M. and Newcombe, C.P. 2008. Towards a classification of organic enrichment in marine sediments based on biogeochemical indicators. Marine Pollut. Bull., 56(5): 810-824.

Homa, E.S. and Chapra, S.C. 2011. Modeling the impacts of calcite precipitation on the epilimnion of an ultraoligotrophic, hard-water lake. Ecol. Model., 222(1): 76-90.

Instituto Municipal de Planeación de Comitán de Domínguez (IMPLAN Comitán). 2015. Management Plan for the Rio Grande basin, Lagunas de Montebello, Chiapas, Mexico. http://transparencia.comitan.gob. mx/ART74/I/DESARROLLO_RURAL/plan_de_gestion_cuencas.pdf

Karami, F., Balci, N. and Guven, B. 2019. A modeling approach for calcium carbonate precipitation in a hypersaline environment: A case study from a shallow, alkaline lake. Ecol. Complex., 39: 100774.

Knossow, N., Blonder, B., Eckert, W., Turchyn, A.V., Antler, G. and Kamyshny, A. 2015. Annual sulfur cycle in a warm monomictic lake with sub-millimolar sulfate concentrations. Geochem. Trans., 16: 7.

Marandi, A. and Shand, P. 2018. Groundwater chemistry and the Gibbs Diagram. Appl. Geochem., 97: 209-212.

Mora, L., Bonifaz, R. and López-Martínez, R. 2016. Geomorphological units of the Río Grande de Comitán basin, Lagos de Montebello, ChiapasMéxico. Bullet. Mexican Geol. Soc., 68(3): 377-394.

Mora, L., García, L.A., Ramos, Y.R., Bonifaz, R. and Escolero, O. 2017. Description of chemical changes in a large karstic system: Montebello, Mexico. Proced. Earth Planet. Sci., 17: 829-832.

Murray, J.W., Jannasch, H.W., Honjo,S., Anderson, R.F., Reeburgh, W.S., Top, Z., Friederich, G.E., Codispoti, L. A. and Izdar, E. 1989. Unexpected changes in the oxic/anoxic interface in the Black Sea. Nature, 338(6214): 411-413.

Nordstrom, D.K. and Campbell, K.M. 2014. Modeling Low-Temperature Geochemical Processes. In Drever, J.I. (ed.), Surface and Ground Water, Weathering, and Soils, In Treatise on Geochemistry. 2nd edition, Vol. 7. Elsevier, The Netherlands, pp. 27-68.

Oseguera, L.A. and Alcocer, J. 2016. Concentration and Vertical Distribution of Particulate Carbon (Total And Organic) In Paz, F.J. and Torres, R. (eds.), Current State of Knowledge of the Carbon Cycle and its Interactions in Mexico: Synthesis to 2015. Mexican Carbon Program in collaboration with the Center for Global Change and Sustainability in the Southeast, A.C and the International Center for Linking and Teaching of the Universidad Juárez Autónoma de Tabasco, Mexico, pp. 457-463.

Parkhurst, D.L. and Appelo, C.A.J. 2013. Description of Input and Examples for PHREEQC Version 3: A Computer Program for Speciation, Batch-Reaction, One-Dimensional Transport, and Inverse Geochemical Calculations. U.S. Geological Survey, USA, p. 159.

Singhal, B.B.S. and Gupta, R P. 2010. Applied Hydrogeology of Fractured Rocks. 2nd edition. Springer, New York.

Stumm, W. 2007. Chemical Processes Regulating the Composition of Lake Waters. In O Sullivan, P.E. and Reynolds, C.S. (eds.), The Lakes Handbook. John Wiley \& Sons, Hoboken, NJ, USA, pp. 79-106

Vera, M.N., Hernández, P., Alcocer, J., Ardiles, V. and Oseguera, L.A. 2015. Concentration and Vertical Distribution of Chlorophyll-A Phytoplankton in the Lakes of Montebello, Chiapas. In Alcocer, J., Merion-Ibarra, E. and Escobar-Briones, E. (eds.), Research Trends in Tropical Limnology: University Perspectives in Latin America. Asociación Mexicana de Limnología, AC, Instituto de Ciencias del Mar y Limnología, UNAM, and Consejo Nacional de Ciencias y Tecnología, pp. 107-114.

Walsh, J.R., Corman, J.R. and Munoz, S.E. 2019. Coupled long-term limnological data and sedimentary records reveal new control on water quality in a eutrophic lake. Limnol. Oceanogr., 64(S1): S34S48. https://doi.org/10.1002/lno.11083.

Zhu, C. and Anderson, G. 2010. Environmental Applications of Geochemical Modeling . Cambridge University Press, Cambridge.

Zhu, C. and Schwartz, F. 2010. Hydrogeochemical processes and controls on water quality and water management. Elements, 7: 169-174. 